\title{
Factors associated with mortality in adult hospitalized burn patients in Tehran
}

\author{
Tahran kentinde hastaneye yatırılan erişkin yanık hastalarında \\ mortaliteye neden olan faktörler
}

\author{
Mohammad-Reza ZAREI, ${ }^{1,2}$ Seyedsaied DIANAT, ${ }^{2}$ Vahid ESLAMI, ${ }^{2}$ Iraj HARIRCHI, ${ }^{3}$ \\ Nosratollah BODDOUHI, ${ }^{4}$ Ali ZANDIEH, ${ }^{2}$ Mohammad R. RASOULI ${ }^{2}$
}

\section{BACKGROUND}

The mortality rate following burn is an important outcome parameter. This study aimed to identify factors associated with mortality in adult hospitalized burn patients in Tehran, Iran.

\section{METHODS}

This cross-sectional study was performed during a oneyear period in two referral burn centers in Tehran. During the study period, 1321 adult ( $>15$ years) hospitalized burn patients were enrolled. Univariate and multivariate (logistic regression) analyses were performed to identify factors associated with mortality.

\section{RESULTS}

The mean age of the patients was $33.1 \pm 14.9$ years. By far, the majority of burns were accidental $(n=1076,81.5 \%)$. Regarding the mechanism of burn, burn with petroleum products was the most frequent. Mean percent burned total body surface area (TBSA) was $39.9 \% \pm 25.8 \%$. The mortality rate was $33 \%$. Sepsis was the most common cause of mortality. The results of the present study indicated that non work-related burns, burned TBSA and body surface area affected by second- or third-degree burns were independent determinants of mortality among adult hospitalized burn patients.

\section{CONCLUSION}

The present study showed a high mortality rate in the studied burn centers. Patients with identified risk factors should be categorized as high risk at the time of admission and need special attention and care during hospitalization.

Key Words: Burn; Iran; mortality; risk factor; total body surface area.

\begin{abstract}
AMAÇ
Yanığı takiben ortaya çıkan mortalite oranı, önemli bir sonuç parametresidir. Bu çalışmada, Tahran'da hastaneye yatırılan erişkin yanıklı hastalarda mortalite ile birlikte olan faktörlerin belirlenmesi amaçlandı.
\end{abstract}

\section{GEREÇ VE YÖNTEM}

$\mathrm{Bu}$ çapraz karşılaştırmalı çalışma, Tahran'daki iki yanık başvuru merkezinde bir yıllık periyotta yapıldı. Çalışma periyodunda hastaneye yatırılan 1321 erişkin ( $>15$ yaş) yanıklı hasta çalışmaya kaydedildi. Mortalite ile birlikte olan faktörleri belirlemek üzere, tek değişkenli analiz ve çok değişkenli (lojistik regresyon) analiz yapıldı.

\section{BULGULAR}

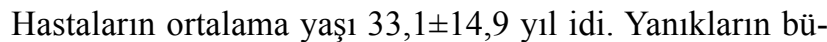
yük çoğunluğu kazaya bağlıydı $(n=1076, \% 81,5)$. Yanık mekanizması ile ilgili olarak, petrol ürünleri ile en sık yanık nedeni idi. Ortalama yüzde yanık toplam vücut yüzey alanı (TVYA) $\% 39,9 \pm \% 25,8$ idi. Mortalite oranı $\% 33$ oldu. Sepsis, en sık mortalite nedeniydi. Bu çalışmanın sonuçlarına göre erişkin yanık hastalarında iş kazası olmayan yanıklar, yanık olan TVYA ve ikinci ve üçüncü derece yanıktan etkilenmiş yüzey alanı mortalitenin bağımsız belirleycileridir.

\section{SONUÇ}

Bu çalışma, çalışılan yanık merkezlerinde yüksek bir mortalite oranı olduğunu göstermiştir. Belirlenen risk faktörleri olan hastalar, yatışları sırasında yüksek riskli hastalar olarak sınıflandırılmalı ve bu hastalara hastanede kalış süresince özel ilgi ve bakım gösterilmelidir.

Anahtar Sözcükler: Yanık; İran; mortalite, risk faktörü; toplam vücut yüzey alanı.

\footnotetext{
${ }^{1}$ Department of Emergency Medicine, Imam Khomeini Hospital, Tehran University of Medical Sciences; ${ }^{2}$ Sina Trauma and Surgery Resaerch Center, Sina Hospital, Tehran University of Medical Sciences;

${ }^{3}$ Department of Surgery, Tehran University of Medical Sciences; ${ }^{4}$ Division of Plastic Surgery, Shahid Motahari Hospital, Tehran University of Medical Sciences, all in Tehran, Iran.
}

${ }^{1}$ Tahran Tibbi Bilimler Üniversitesi, İmam Humeyni Hastanesi, Acil Tip Bölümü; ${ }^{2}$ Tahran Tibbi Bilimler Üniversitesi, Sina Hastanesi, Sina Travma ve Cerrahi Araştırma Merkezi; ${ }^{3}$ Tahran Tibbi Bilimler Üniversitesi, Cerrahi Bölümü; ${ }^{4}$ Tahran Tıbbi Bilimler Üniversitesi, Shahid Motahari Hastanesi, Plastik Cerrahi Bölümü, Tahran, İran. 
Burns are a global public health concern affecting about $1 \%$ of the general population annually. In addition to the physical and psychological morbidity that burns impose upon the injured patients and their families, these types of injuries are associated with a huge financial burden on the medical care system..$^{[1,2]}$

Advances in burn care and understanding some aspects of the pathophysiologic process of burns have motivated researchers to identify risk factors for mortality in burn patients, resulting in the development of several models for the prediction of mortality following burn. ${ }^{[3-5]}$ These models are of great value, enabling the physician to recognize patients who are more likely to recover fully or those with determinant factors that are life-threatening. Development of these models can be used as an effective tool for management and triage of burn patients in burn care centers and in general hospitals, so that patients with higher risk of mortality can be referred to specialized burn care centers for more effective management after initial resuscitation. ${ }^{[6]}$

According to previous reports from Iran, ${ }^{[7,8]}$ the mortality rate of hospitalized burn patients is much higher than in developed countries ${ }^{[9-13]}$ As most of the introduced models have been designed based on data from developed countries, these models may not be fully compatible with the situation of burn care in developing countries like Iran. ${ }^{[14-17]}$

To the best of our knowledge, there is no report from Iran to introduce a comprehensive model to predict mortality in hospitalized burn patients. In this study, besides demonstrating the epidemiologic profile of adult hospitalized burn patients in two burn centers in Tehran, we aimed to identify risk factors for mortality in these patients.

\section{MATERIALS AND METHODS}

After approval of the ethical committee on human research of Tehran University of Medical Sciences, a cross-sectional study was performed during a one-year period in two referral burn centers in Tehran (Tohid and Motahhari Hospitals). For this study, all adult (age $>15$ years) burn patients hospitalized within the period of the study were enrolled. Data were collected by trained physicians, who completed a prepared questionnaire for each patient at the time of emergency room admission. They also followed the patients during hospitalization and collected the required data.

The following data were obtained for each patient: age, sex, mechanism of burn, total percent of burned total body surface area (TBSA) and percent of TBSA affected by each burn degree (first-, second- and thirddegree), procedures performed in patients including escharotomy, debridement, and tracheal intubation, outcome of the injury (death or survival), and cause of death.

Statistical analysis was performed using SPSS (SPSS Inc., Chicago, IL, version 16) and MedCalc (Maria-kerke, Belgium, version 9.2). All quantitative data were expressed as mean \pm standard deviation. The patients were categorized into two groups, as survivors and non-survivors. Univariate analysis was performed using independent samples t test and chi-square analysis for quantitative and qualitative variables successively. Multivariate analysis (logistic regression) was carried out to determine risk factors for mortality. For this purpose, receiver operating characteristic (ROC) analysis was done to identify cut-off values for burned TBSA and TBSA affected by second- and third-degree burns. These variables were then categorized into two groups based on the obtained cut-off points and entered into the multivariate analysis. The body surface areas were categorized into two groups based on cut-off values obtained from ROC analysis. For logistic regression analysis, age was categorized into four groups as follows: $<50,50$ $64,65-80$, and $>80$ years. ${ }^{[18]}$

\section{RESULTS}

During the study period, 1321 patients (964 males [73\%]) were enrolled into the study. Six hundred seventy-seven (51.2\%) and $644(48.8 \%)$ successive cases were from Tohid and Motahari hospitals, respectively. The mean age of the patients was $33.1 \pm 14.9$ years. Burns had most commonly occurred in homes and factories, accounting for $762(57.7 \%)$ and $232(17.6 \%)$ of cases, respectively. By far, the majority of burns were accidental $(n=1076,81.5 \%)$ followed by deliberate self-burn $(\mathrm{n}=159,12 \%)$ and assault $(\mathrm{n}=51,3.9 \%)$. Work-related burns accounted for $287(21.7 \%)$ of the burns. Regarding the mechanism of burn, burns with petroleum products were the most frequent. Fig. 1 depicts the details.

The upper extremity was the most frequently burned site, affected in 1230 cases. Fig. 2 demonstrates the frequency of the involved body site. Mean burned

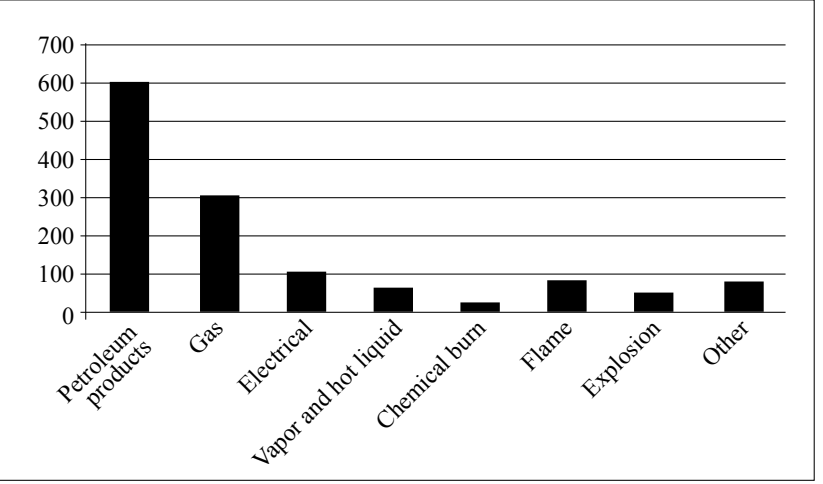

Fig. 1. The frequency of each mechanism of burn. 
Table 1. Risk factors for mortality in univariate analysis

\begin{tabular}{llcc}
\hline Variable & & $\begin{array}{c}\text { Outcome (dead) } \\
(\mathrm{n}=437)\end{array}$ & $\mathrm{p}$ \\
\hline Sex & Male & $274(62.7 \%)$ & $<0.001^{\dagger}$ \\
& Female & $163(37.3 \%)$ & \\
Escharotomy & Yes & $50(11.5 \%)$ & $<0.001^{\dagger}$ \\
& No & $384(88.5 \%)$ & \\
Work-related burn & Yes & $59(13.5 \%)$ & $<0.001^{\dagger}$ \\
& No & $378(86.5 \%)$ & \\
Tracheal intubation & Yes & $10(90.9 \%)$ & $<0.001^{\ddagger}$ \\
& No & $1(9.1 \%)$ & \\
\hline
\end{tabular}

${ }^{\dagger}$ Chi-square; ${ }^{\dagger}$ Fishers exact test.

TBSA was $39.9 \% \pm 25.8 \%$. Debridement and escharotomy were carried out in $89(6.7 \%)$ and $74(5.6 \%)$ of the cases, respectively. Eleven subjects $(0.8 \%)$ underwent tracheal intubation while only one case $(0.1 \%)$ required tracheostomy.

Four hundred thirty-seven cases (33.1\%) died. Sepsis was the most common cause of mortality, occurring in 277 cases $(63.6 \%)$, followed by respiratory failure in $109(24.9 \%)$ and renal failure in $12(2.7 \%)$. The mean age of the patients classified as non-survivors and survivors was $34.3 \pm 16.8$ and $32.5 \pm 14$ years, respectively, which was not statistically significant $(\mathrm{p}=0.055)$. Univariate analysis revealed a significant association between mortality and sex, non work-related burns, not performing escharotomy, burned TBSA, and second- and third-degree burned body surface area (Tables 1, 2). Further, burn with petroleum products accounted for $62 \%(n=271)$ of mortalities $(p<0.001)$. We also found some cut-off values for burned TBSA using ROC analysis. These cut-off values were 35.5\%, $13 \%$ and $43 \%$, respectively, for second-degree, thirddegree and burned TBSA. These variables were categorized into two groups based on these values and then entered into multivariate analysis.

Logistic regression analysis showed the association between mortality and burned TBSA, burned body surface area with second- and third-degree burns, and non work-related burn injuries (Table 3).

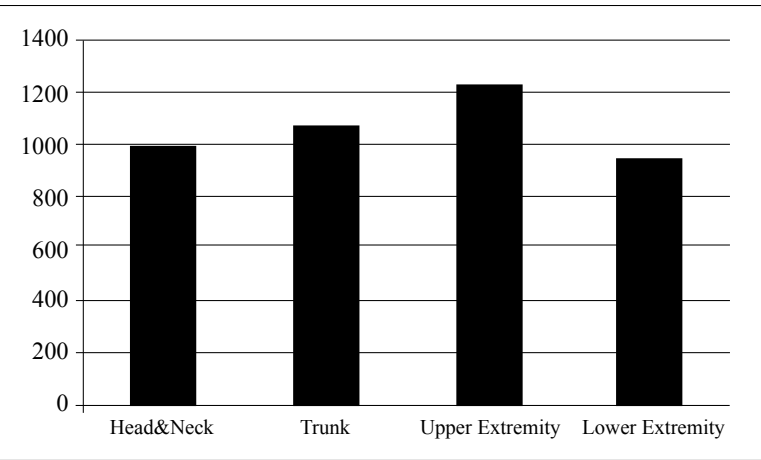

Fig. 2. Distribution of burned sites of the body among the patients.

\section{DISCUSSION}

The results of the present study indicated that non work-related burns, burned TBSA and body surface area affected by second- or third-degree burns are independent determinant factors of mortality among adult hospitalized burn patients.

The mortality rate in our series of patients was $33 \%$, which is higher than in most of the reports from other countries. ${ }^{[9,10,12,13,19]}$ However, it is relatively similar to the mortality rates that have been reported from Iran. In a study by Soltani et al. ${ }^{[20]}$ conducted in Tehran, the mortality rate was $51 \%$ in males and $69 \%$ in females. Another report by Groohi et al. ${ }^{[21]}$ revealed that overall case fatality rate among patients admitted to burn units in Kurdistan was 33.4\%. The high rate of mortality in hospitalized burn patients in our study may be explained in part by the lack of a sufficient number of burn care centers in Tehran and surrounding cities, leading to a high number of patients admitted in these centers, thereby making the management of these patients difficult. Another issue is the delayed or inefficient management of burn patients in general hospitals and delayed referral of those severely injured patients who need more specialized care in burn care centers. The high rate of pseudomonas infection among hospitalized burn patients in Iranian burn care centers has been reported previously and may have an important impact on the high mortality rate. ${ }^{[22]}$

Cause of death in hospitalized burn patients varies in different studies, and sepsis, multiple organ failure and inhalation injury have been reported as the main causes of death in burn patients. ${ }^{[16,19,23]}$ The most common cause of death in our study was sepsis. This was similar to another study in Kuwait. ${ }^{[19]}$ In a study on major burns in Tokyo, cause of early death within 30 days of admission was shock and inhalation injury. In addition, long-term cause of mortality was multiple organ failure. ${ }^{[23]}$ In another study by Ryan et al., ${ }^{[16]}$ the most frequent cause of death was multiple organ failure.

There are extensive studies investigating the role of various risk factors for mortality following burn injury. Some authors have consistently reported age, TBSA and inhalation injury as risk factors of mortality in burn patients. ${ }^{[7,16,23-26]}$ We did not find an association between age and mortality in our study, which is consistent with a study conducted in the Netherlands. ${ }^{[27]}$ In accord with previous reports on the role of TBSA as an independent risk factor for mortality, ${ }^{[7,16,23,24]}$ we similarly found a significant association between TBSA and mortality. We have also proposed some cut-off values for second- and third-degree and burned TBSA for prediction of mortality in burn patients. We found that burned TBSA of more than $43 \%$ has a significant association with mortality. Ryan et al. ${ }^{[16]}$ also demon- 
Table 2. Percent of burned total body surface area and percent of body surface area affected by second- and third-degree burns

\begin{tabular}{lccc}
\hline Variable (mean \pm SD) & $\begin{array}{c}\text { Non-survivors } \\
(\mathrm{n}=437)\end{array}$ & $\begin{array}{c}\text { Survivors } \\
(\mathrm{n}=884)\end{array}$ & $\mathrm{p}$ \\
\hline Percent area of second-degree burn & $55.1 \pm 24.0$ & $24.7 \pm 14.9$ & $<0.001$ \\
Percent area of third-degree burn & $34.5 \pm 27.5$ & $6.9 \pm 6.1$ & $<0.001$ \\
Percent TBSA & $66.2 \pm 21.3$ & $26.1 \pm 14.9$ & $<0.001$ \\
\hline
\end{tabular}

SD: Standard deviation; TBSA: Total body surface area.

Table 3. Variables having significant association with mortality in multivariate analysis

\begin{tabular}{lccccc}
\hline Variable & $\beta$ & $\mathrm{p}$ & $\operatorname{Exp}(\beta)$ & \multicolumn{2}{c}{$95 \% \mathrm{CI}$} \\
\cline { 5 - 6 } & & & & Upper & Lower \\
\hline Second-degree TBSA & 1.383 & 0.024 & 3.987 & 1.199 & 13.260 \\
Third-degree TBSA & 3.267 & $<0.001$ & 26.241 & 8.859 & 77.728 \\
Percent TBSA & 3.049 & $<0.001$ & 21.087 & 6.257 & 71.072 \\
Non work-related & 1.305 & 0.019 & 3.687 & 1.237 & 10.995 \\
Constant & -5.335 & $<0.001$ & 0.005 & - & - \\
\hline
\end{tabular}

CI: Confidence interval; TBSA: Total body surface area.

strated that TBSA of more than $40 \%$ is a significant risk factor for mortality in burn patients. In our study, those patients requiring tracheal intubation had a higher rate of morality compared with those in whom tracheal intubation was not needed. Although we do not have the rate of inhalation injury in our study, this may be an indicator of inhalation injury necessitating tracheal intubations, which has been reported as a risk factor for mortality. ${ }^{[16]}$

Non work-related burn was a risk factor for mortality in our study. Similarly, in a study by Bang et al., ${ }^{[19]}$ domestic accidental burn was detected as a risk factor for mortality. In addition, we found that those with need for escharotomy had lower rate of mortality; however, no significant difference was detected after logistic regression analysis. Similar to our study, Ryan et al. ${ }^{[16]}$ found no significant association between need for escharotomy and mortality. However, in another study on patients with severe burns, need for escharotomy was a significant predictor of mortality. ${ }^{[28]}$

There is controversy about gender differences in the mortality of burn patients. Some investigators have demonstrated that female gender is a risk factor for mortality in burn patients. ${ }^{[6,29,30]}$ In a study by McGwin et al., ${ }^{[14]}$ female burn patients aged less than 60 years had an increased risk of death compared with males. This association persisted following adjustment for burn size, burn depth and inhalation injury. On the other hand, some researchers have found no significant association between gender differences and mortality in burn patients. ${ }^{[23]}$ In a larger study by Brusselaers al., ${ }^{[31]}$ a higher but statistically insignificant mortality rate was observed in male burn patients ( $1.6 \%$ male, $1.1 \%$ female). Similar to the last report by Blot et al., we identified a higher mortality rate in male burn patients. However, this association was not persistent following multivariate logistic regression analysis, indicating no independent role of gender on mortality in burn patients. This may suggest that other confounding factors affect this association.

This study had some limitations, perhaps the most important of which was the lack of data on inhalation injury.

In conclusion, the present study showed a high mortality rate in the studied burn centers, which may be due to the lack of a sufficient number of burn care centers in Tehran and surrounding cities, the lack of a suitable multidisciplinary approach and delayed referral to burn centers of burn patients from the emergency ward of general hospitals. In the present study, non work-related burns, burned TBSA, and body surface area affected by second- or third- degree burns were independent predictors of mortality. The patients with these risk factors should be categorized as high risk at the time of admission and need special attention and care during hospitalization.

\section{Acknowledgement}

This study was supported by a grant from Sina Trauma and Surgery Research Center, Tehran University of Medical Sciences.

\section{REFERENCES}

1. Macedo JL, Santos JB. Predictive factors of mortality in burn patients. Rev Inst Med Trop Sao Paulo 2007;49:365-70.

2. Mashreky SR, Rahman A, Chowdhury SM, Giashuddin S, SvanstrOm L, Linnan M, et al. Epidemiology of childhood burn: yield of largest community based injury survey in Bangladesh. Burns 2008;34:856-62. 
3. Hilal A, Cekin N, Arslan M, Gulmen M. Deaths due to burns in Adana, Turkey. Burns 2008;34:982-5.

4. Belgian Outcome in Burn Injury Study Group. Development and validation of a model for prediction of mortality in patients with acute burn injury. Br J Surg 2009;96:111-7.

5. McGwin G Jr, George RL, Cross JM, Rue LW. Improving the ability to predict mortality among burn patients. Burns 2008;34:320-7.

6. Gomez M, Wong DT, Stewart TE, Redelmeier DA, Fish JS. The FLAMES score accurately predicts mortality risk in burn patients. J Trauma 2008;65:636-45.

7. Panjeshahin MR, Lari AR, Talei A, Shamsnia J, Alaghehbandan R. Epidemiology and mortality of burns in the South West of Iran. Burns 2001;27:219-26.

8. Lari AR, Alaghehbandan R, Nikui R. Epidemiological study of 3341 burns patients during three years in Tehran, Iran. Burns 2000;26:49-53

9. Barret JP, Gomez P, Solano I, Gonzalez-Dorrego M, Crisol FJ. Epidemiology and mortality of adult burns in Catalonia. Burns 1999;25:325-9.

10. Rimdeika R, Kazanavicius M, Kubilius D. Epidemiology of burns in Lithuania during 1991-2004. Medicina (Kaunas) 2008;44:541-7.

11. da Silva PN, Amarante J, Costa-Ferreira A, Silva A, Reis J. Burn patients in Portugal: analysis of 14,797 cases during 1993-1999. Burns 2003;29:265-9.

12. De-Souza DA, Marchesan WG, Greene LJ. Epidemiological data and mortality rate of patients hospitalized with burns in Brazil. Burns 1998;24:433-8.

13. Garner WL, Reiss M. Burn care in Los Angeles, California: LAC+USC experience 1994-2004. Burns 2005;31:S32-5.

14. McGwin G Jr, George RL, Cross JM, Reiff DA, Chaudry IH, Rue LW 3rd. Gender differences in mortality following burn injury. Shock 2002;18:311-5.

15. George RL, McGwin G Jr, Schwacha MG, Metzger J, Cross JM, Chaudry IH, et al. The association between sex and mortality among burn patients as modified by age. J Burn Care Rehabil 2005;26:416-21.

16. Ryan CM, Schoenfeld DA, Thorpe WP, Sheridan RL, Cassem EH, Tompkins RG. Objective estimates of the probability of death from burn injuries. N Engl J Med 1998;338:362-6.

17. Pham TN, Kramer CB, Wang J, Rivara FP, Heimbach DM,
Gibran NS, et al. Epidemiology and outcomes of older adults with burn injury: an analysis of the National Burn Repository. J Burn Care Res 2009;30:30-6.

18. Belgian Outcome in Burn Injury Study Group. Development and validation of a model for prediction of mortality in patients with acute burn injury. Br J Surg 2009;96:111-7.

19. Bang RL, Sharma PN, Gang RK, Ghoneim IE, Ebrahim MK. Burn mortality during 1982 to 1997 in Kuwait. Eur J Epidemiol 2000;16:731-9.

20. Soltani K, Zand R, Mirghasemi A. Epidemiology and mortality of burns in Tehran, Iran. Burns 1998;24:325-8.

21. Groohi B, Alaghehbandan R, Lari AR. Analysis of 1089 burn patients in province of Kurdistan, Iran. Burns 2002;28:56974.

22. Lari AR, Alaghehbandan R. Nosocomial infections in an Iranian burn care center. Burns 2000;26:737-40.

23. Kobayashi K, Ikeda H, Higuchi R, Nozaki M, Yamamoto Y, Urabe M, et al. Epidemiological and outcome characteristics of major burns in Tokyo. Burns 2005;31 Suppl 1:S3-S11.

24. Laloë V. Epidemiology and mortality of burns in a general hospital of Eastern Sri Lanka. Burns 2002;28:778-81.

25. Waller AE, Marshall SW, Langley JD. Adult thermal injuries in New Zealand resulting in death and hospitalization. Burns 1998;24:245-51.

26. Han TH, Kim JH, Yang MS, Han KW, Han SH, Jung JA, et al. A retrospective analysis of 19,157 burns patients: 18-year experience from Hallym Burn Center in Seoul, Korea. Burns 2005;31:465-70.

27. Bloemsma GC, Dokter J, Boxma H, Oen IM. Mortality and causes of death in a burn centre. Burns 2008;34:1103-7.

28. Ryan CM, Sheridan RL, Schoenfeld DA, Warshaw AL, Tompkins RG. Postburn pancreatitis. Ann Surg 1995;222:163-70.

29. Muller MJ, Pegg SP, Rule MR. Determinants of death following burn injury. Br J Surg 2001;88:583-7.

30. O'Keefe GE, Hunt JL, Purdue GF. An evaluation of risk factors for mortality after burn trauma and the identification of gender-dependent differences in outcomes. J Am Coll Surg 2001;192:153-60.

31. Brusselaers N, Juhász I, Erdei I, Monstrey S, Blot S. Evaluation of mortality following severe burns injury in Hungary: external validation of a prediction model developed on Belgian burn data. Burns 2009;35:1009-14. 